\title{
Analysis Of Value Added From Results Of Catfish Fishing Trawling Kite In The Village Of Bagan Percut District Percut Sei Tuan Regency Deli Serdang
}

\author{
Ramli \\ Department of Economic Development \\ Universitas Sumatera Utara \\ Medan, Indonesia \\ ramlihan_usu@ymail.com
}

\begin{abstract}
The phenomenon of economic inequality between coastal cities and villages is a key issue for economic development. Breakthrough development strategies need to be sought in order to overcome poverty and equitable development outcomes. Regional economic development, implemented by the government is limited by financing sources in order to realize the planning action is not accommodated in the present. The purpose of this study is to analyze the neglected economic value of the remaining catches of trawler fishermen, an inventory of various economic commodities that can be produced from the remaining catches of trawler fishermen and add economic value added and the management of the residual catch of trawling that is processed into economic commodities. The method used for primary data collection with observation and experimental techniques. Primary data is obtained directly from official publications. Data analysis used descriptive and comparative technique before and after handling. The result of the catch of trawler fisherman has economic market value as consumed ingredients of anchovy, salted fish, as raw material for making fish feed and as jewelry and accessories. The value of potential economic commodities from the remaining catches of trawler fisherman: anchovy, shellfish, shrimp centipedes, small squid, leather siteng, small fish. Value added to commodities that can be consumed, anchovies, squid, small shrimp / centipedes and small fish. The value added of small crabs, small fish and small shrimp / shrimp can be used as a food powder for feed raw materials.
\end{abstract}

Keywords-Residual of Catch, Commodity of Economic Potential, Value Added.

\section{INTRODUCTION}

Development is basically a process of realize a better state of the present day compared to past conditions. North Sumatra Province based on topography has a highland area that produces vegetable production, and the last coastal lowland areas of fish production. The production of these two areas as the center of urban supply supplier need of the city, but some of the population in this region is still shackled by a cycle of impoverished poverty and parts of it into pockets of poverty. A Development plan, both before regional autonomy and after regional autonomy, has yet to show the gap between the urban and rural to enjoying development outcomes.

The coastal rural development strategy pursued has not resulted in better outcomes, among others: the gap between rich and poor is widening, the infrastructure gap between towns and villages, the economic institutional disparities between urban and rural areas. Technology access gap between city and village. This gap makes villages economies unable to rise up and cut out the circle of poverty (vicious circle of poverty).

In the village of Bagan Percut, the tendency of fishermen to catch fish by means of trawler who went in the afternoon and went home tomorrow and the location of the catch not far from the coastal boundary. The catchment of trawler targeted specifically for catching shrimp, the average duration of once catching 4 hours of fish and one fishing trap averaging 4 to 5 times the trawl net. The average catch of approximately $2 \mathrm{~kg}$ consisting of shrimp, crab, cuttlefish, squid, tongue and octopus fish.

The remaining catches of trawler fishermen need to be done Utility of form through an innovative process of technology so that it becomes useful and is a value added (value added), income sources and make revenue area Percut, District of Percut Sei Tuan Deli Serdang.

In order for the rest of the catch fishermen can be useful, it is necessary to do research observations and experiments that are packed with the title "Analysis of Value Added From Residual Catch of Trawler Fisherman in Bagan Percut Village Percut Sei Tuan Sub-District Deli Serdang Regency". 


\section{A. Formulation Of The Problem}

1. How much economic value is neglected from the remaining catches of the trawler fisherman

2. The value of the variety of economic commodities that can be produced from the remaining catches of trawler fisherman

3. Value added of Economic from the management of the remaining catches of trawl that are processed into fish powder.

\section{B. Paradigm of Regional Development}

The science of regional development is the integration of various theories and applied sciences namely, geography, economics, sociology, mathematics, statistics, political science, regional planning, environmental science and so on. The science of regional development is a discipline that is supported by four pillars of geography, economy, city planning and location theory. Development of coastal areas and oceans using integrated regional development approach at least noticed six aspects, which are the pillars of regional development, can be seen in the following figure [1].

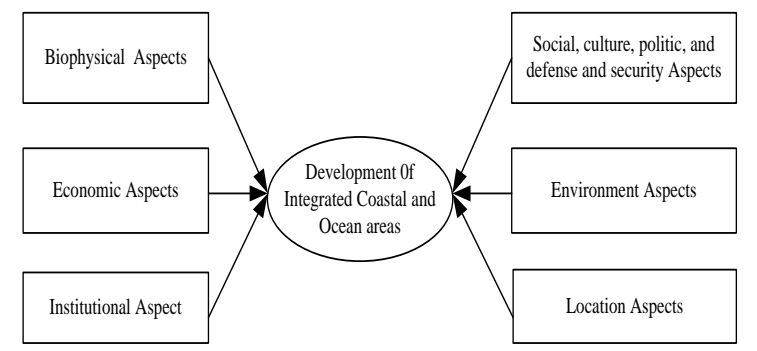

Figure 1. Pillars of Integrated Coastal Area Development

Regional autonomy based on Law No.32 / 33 of 2004 which authorizes the regions to regulate their own households with the principles of democracy, community participation, equity, and justice and attention to the potential and diversity of the region. North Sumatra has highland and lowland topography that has the economic potential of natural resources, artificial culture, and institutions that can be mobilized into regional economic movement. However, this potential has not been optimally mobilized for income generating areas, possibly due to inadequate supporting infrastructure facilities. [2]

Building a sustainable coastal area can minimize the poverty of the structure and impoverish the cultural community of fishermen, through the agromerin politan program, but the agromerin politan program of North Sumatera province has not maximally boosted the coastal economy described from the lack of coordination, integrity and synchronization [3].

In general, in the coastal village of Percut, it is generally dependent on the life of fish resources that have seasons and sea time, the existence of the connective resources does not guarantee a better life. So they are shackled in an endless cycle of poverty. Many opportunities and the chance of family in improving economic capability based on the regional economic potential, but the constraints is the limitation of creative effort, it is necessary to build entrepreneurship motivation program among the coastal community Bagan Percut Percut Sei Tuan District Deli Serdang Regency [4].

\section{Previous Research}

Preliminary studies that have been conducted include a study of literature on the economic development of coastal areas still highlight the characteristics of fishermen with various internal and external. Such As the Analysis of the Technology Transfer Model of the Swamp Area [5].

Fishermen Poverty Assessment Studies on economic value added from fisherman catches to date have not been studied. This study will contribute to the theoretical and methods and solving problems in coastal economic development and increase in fisherman income [6].

Economic development of coastal areas focusing on the multiplication of the potential of natural resources Efforts to increase the productivity of community economic activities and efforts to increase the added value of the economic sector of a regency/city is needed a strategic program that can unite the power of economic potential to conduct a series of economic activity processes in generating the regional economic reactions.

There is a difference in the production and income levels of the tide and cantrang tools used. The income of the fisherman is good compared to the income of the fisherman although the production level differs from the different fishing cantrang, as well as the income level. Greater income levels than fishing gear used, but the level of income is still low compared to the needs of decent living [7]

\section{Research Purpose}

1. To analyze the neglected economic value of the remaining catches of the trawler kite.

2. To analyze the value of the variety of economic commodities that can be produced from the remaining catches of trawler fishing trawler kite.

3. To analyze the economic added value of the management of residual fishing gull trawl which in the process of becoming fish powder.

\section{RESEARCH METHOD}

Withdrawal samples used by fishing trawler used is proportional sampling technique, that is the technique of determining the sample based on the objective means that fishermen who work as fishermen meet with enumerator can be sampled.

Primary data collection was collected directly from the respondents / samples by interview technique based on the questionnaires that have been developed. The data from a treatment is shown directly. Secondary data collection is obtained directly from official agencies, such as BPS, Printing in the form of Annual Reports, Books, journal with direct recording techniques. Sample Size The sample size used to represent the specified sample was 30 people and the magnitude of the treatments was 50 events [8]. 
Data Analysis to explain the first problem, the neglected economic value of the remaining catches of fishermen is done by comparative technique after the utility is done with the following actions.

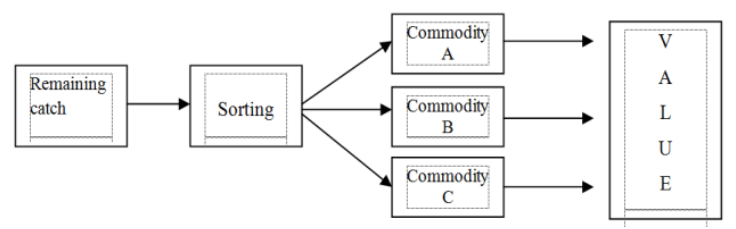

Figure 2. Commodity and Value Determination Process

\section{RESEARCH RESULT}

\section{A. Raw materials for consumption}

$2 \mathrm{Kg}$ of this catch is still $5 \%$ of all catches, while $95 \%$ of it is garbage or the rest of the catch is not useful for fishermen and thrown back to the sea. The remainder of this catch consists of fine fish, fine shrimp, seashells, umang and crabs that cannot be eaten.

The rest of the fishermen's crops, which are thrown back to the sea, have the economic value of waste disposed, seen to be an eating material can be anchovies, small shrimp, crabs and small fish. The result of garbage collected from fishermen is 32 times and the total weight of wet waste is $2.523,25 \mathrm{~kg}$. After the sorting of waste or the remaining catches of trawler fishermen, obtained anchovies as much as $122.8 \mathrm{~kg}$. The process of sorting the waste or the remaining catches of trawler fishermen, obtained by small fish as much as $122.8 \mathrm{~kg}$. The process of sorting the waste or the remaining catches of trawling fishermen obtained small shrimp / shrimp centipede as much as $51.9 \mathrm{~kg}$. For small squid $9.1 \mathrm{~kg}$. Result of sorting to garbage or the remnants of fishermen catching trawlers obtained small crabs $617.9 \mathrm{~kg}$. Seashell / snail counted 104.25. The result of sorting to the waste or the remnant of catching fish of seine trawl obtained by the shell skin of $47.4 \mathrm{Kg}$, and the result of sorting to the waste or the remnant of the fisherman catching trawlers obtained the useless organic waste of $748.8 \mathrm{Kg}$. Depreciation of the remaining catches of trawling fishermen into small fish $12.55 \mathrm{~kg}$, anchovy $3.9 \mathrm{~kg}$, small shrimp / centipedes $9.8 \mathrm{~kg}$, small squid $0.75 \mathrm{~kg}$, small crabs $135.1 \mathrm{~kg}$, shell / snail $81.12 \mathrm{~kg}$, shell shells $36.6 \mathrm{Kg}$ and organic waste of $350.71 \mathrm{~kg}$. In detail can be seen in the following table.

Table 1. Wet Totality and Depreciation of Fishers' Fishing Time

\begin{tabular}{|c|r|r|r|r|r|}
\hline & $\begin{array}{c}\text { Total } \\
\text { Input (Kg) }\end{array}$ & $\begin{array}{c}\text { Small } \\
\text { Fish } \\
(\mathrm{Kg})\end{array}$ & $\begin{array}{c}\text { Anchovy } \\
(\mathrm{Kg})\end{array}$ & $\begin{array}{c}\text { Centipede } \\
\text { Shrimp (Kg) }\end{array}$ & $\begin{array}{c}\text { Small } \\
\text { squid } \\
(\mathrm{Kg})\end{array}$ \\
\hline $\begin{array}{c}\text { Before } \\
\text { drying }\end{array}$ & $2.523,25$ & 122,8 & 23,9 & 51,9 & 9,1 \\
\hline $\begin{array}{c}\text { After } \\
\text { drying }\end{array}$ & 508,53 & 12,55 & 3,9 & 9,8 & 0,75 \\
\hline Price & & 20.000 & 40.000 & 4.000 & 25.000 \\
\hline
\end{tabular}

Table 1. Cont

\begin{tabular}{|c|r|r|r|c|}
\hline & $\begin{array}{c}\text { Small crab } \\
(\mathrm{Kg})\end{array}$ & $\begin{array}{c}\text { Leather shell } \\
(\mathrm{Kg})\end{array}$ & $\begin{array}{c}\text { Ornamental } \\
\text { shell }(\mathrm{Kg})\end{array}$ & $\begin{array}{c}\text { Organic } \\
\text { trash } \\
(\mathrm{Kg})\end{array}$ \\
\hline $\begin{array}{c}\text { Before } \\
\text { drying }\end{array}$ & 617,9 & 104,25 & 47,4 & 748,8 \\
\hline $\begin{array}{c}\text { After } \\
\text { drying }\end{array}$ & 135,1 & 81,12 & 36,6 & 350,71 \\
\hline Price & $\begin{array}{c}\text { feed } \\
\text { ingredients }\end{array}$ & feed ingredients & feed ingredients & - \\
\hline
\end{tabular}

The economic value derived from each commodity for anchovy is worth IDR 156.000, - (assuming an anchovy market price of IDR 40.000 per $\mathrm{kg}$ ). Small fish IDR 313.750, (assuming a small fish price of IDR 25.000).

The creamy shrimp is worth IDR 39.200, - (assuming the price of small shrimp / centipedes IDR 4,000). Small squid is worth IDR 18.750, - (assuming small squid price IDR 25.000, and in detail the value of each small commodity fish, small fish and small shrimp can be seen in the following table:

Table 2. Value Added of Anchovy, Small Fish and Dried Fish

\begin{tabular}{|c|c|r|r|r|}
\hline No & Commodity & $\begin{array}{c}\text { Wet } \\
\text { Quantity } \\
(\mathrm{kg})\end{array}$ & $\begin{array}{c}\text { Dry } \\
\text { Quantity } \\
(\mathrm{Kg})\end{array}$ & $\begin{array}{c}\text { Processing } \\
\text { costs }\end{array}$ \\
\hline 1. & Anchovy & 23.90 & 3.90 & 11,950 \\
\hline 2. & Small fish & 122.80 & 12.55 & 61,400 \\
\hline 3. & $\begin{array}{c}\text { Shrimp } \\
\text { centipede }\end{array}$ & 51.90 & 9.80 & 25,950 \\
\hline 4. & Small squid & 9.10 & 0.75 & 20,000 \\
\hline
\end{tabular}

Table 2. Cont

\begin{tabular}{|c|c|r|r|r|}
\hline No & Commodity & $\begin{array}{c}\text { Market } \\
\text { price }\end{array}$ & $\begin{array}{c}\text { Value } \\
\text { potency }\end{array}$ & \multicolumn{1}{c|}{$\begin{array}{c}\text { Value } \\
\text { added }\end{array}$} \\
\hline 1. & Anchovy & 40,000 & 156,000 & 144,050 \\
\hline 2. & Small fish & 25,000 & 313,750 & 252,350 \\
\hline 3. & $\begin{array}{c}\text { Shrimp } \\
\text { centipede }\end{array}$ & 4,000 & 39,200 & 13,250 \\
\hline 4. & Small squid & 25,000 & 18,750 & 1,250 \\
\hline
\end{tabular}

The value added of obtained from anchovies is IDR. 144,050 , - added value is obtained from the centipedes of shrimp IDR. 252,350, -, the added value of small fish is IDR. 13,250 , - and for the added value of small squid of IDR. 1.250, -. The rest of the catches of most of the trawl fishermen are small crabs. This small crab is not edible (according to the fisherman's description because it is poisonous) and the size of the crab is $4 \mathrm{~cm}$ and is not economically used as food. But, the crab has a high potential for processed into animal feed ingredients, in the form of fish meal that can be used as the main ingredient of making fish feed. The potential value of small crabs used as powder feed of IDR. 607,950, - and the added value obtained from the feed powder of IDR. 337,750, -. The value of potential small shrimp used as powder feed for IDR. 52.920, -. The added value obtained from the feed flour is 
IDR. 33.320, - and small fish the potential value obtained is IDR. 45,180, - and this added value is used as fish meal for IDR. 20,080, -. In detail can be seen in the following table:

Table 3. Value Added of Small Crab, Chocolate Cage and Small Fish

\begin{tabular}{|l|c|c|c|c|}
\hline No & Commodity & $\begin{array}{c}\text { Wet } \\
\text { Quantity } \\
(\mathrm{kg})\end{array}$ & $\begin{array}{c}\text { Dry } \\
\text { Quantity } \\
(\mathrm{Kg})\end{array}$ & $\begin{array}{c}\text { Processing } \\
\text { cost }\end{array}$ \\
\hline 1. & Small crab & 617,9 & 135,1 & 270.200 \\
\hline 2. & $\begin{array}{c}\text { Shrimp } \\
\text { centipede }\end{array}$ & 51,9 & 9,8 & 19.600 \\
\hline 3. & Small fish & 122,8 & 12,55 & 25.100 \\
\hline
\end{tabular}

Table 3. Cont

\begin{tabular}{|c|c|c|c|c|c|}
\hline No & Commodity & $\begin{array}{c}\text { Quantity } \\
\text { after } \\
\text { processing }\end{array}$ & $\begin{array}{c}\text { Market } \\
\text { price }\end{array}$ & $\begin{array}{c}\text { Potential } \\
\text { value }\end{array}$ & $\begin{array}{c}\text { Value } \\
\text { added }\end{array}$ \\
\hline 1. & Small crab & 121,59 & 5.000 & 607.950 & 337.750 \\
\hline 2. & $\begin{array}{c}\text { Shrimp } \\
\text { centipede }\end{array}$ & 8,82 & 6.000 & 52.920 & 33.320 \\
\hline 3. & Small fish & 11,295 & 4.000 & 45.180 & 20.080 \\
\hline
\end{tabular}

Noted: Processing cost/ $\mathrm{Kg}=2.000$

Depreciation to flour averages 1 ounce of $1 \mathrm{~kg}$ of raw materials.

\section{B. Raw materials for decoration}

The result of observation from the remaining waste of fisherman catch fish trawl that potentially become decoration products such as curtains, accessories, cigarette ashtray, tissue box. The potential value of waste/waste. Catch fishermen can be shell/thin shell, shell snail, etc.

\section{DISCUSSION}

The potential of natural resources directed to increase the added value is a breakthrough in tackling the poverty level of coastal communities. Breakthrough activities must be integrated with other coordinated activities programs with rural economic development planning. Economic development of villages through the action of added value of various types of waste, the catchment of fishermen trawl is prepared in a comprehensive and coordinated management. Coastal economic development is very dependent on the preparation of natural resource utilization planning in an area. Preparation of detailed plan planning from coastal economic development activities from various economic sectors needs to be elaborated in a regional policy document. Managing coastal economies by empowering the capacity of coastal communities in the need of a team work established by the local government, the working group will draw up a plan of action programs to improve the local economy through a range of measures to increase the added value of the various elements of the remaining catches of the trawler fishermen. The action programs that are developed need input from various government and stakeholders. This action program document is the basis for the actions of the working groups, government and stakeholders. The document of this action program as the basis for the action of the working group, the government and the stakeholders and the management is autonomous for the working group or all the costs required for operational activities at the cost of government and other non-binding sources.

\section{CONCLUSIONS AND SUGGESTIONS}

\section{A. Conclusion}

Based on the experimental action on the remaining catches of the trawler fisherman can be summarized as follows:

1. The remaining catches of trawler fishermen have value added of economic potential as raw materials and consumption materials. The remaining catches of trawler fishing contain various economic potential values: Anchovy, Small Shellfish, Big Shells, Lipan Shrimp, Siteng Leather, small crabs.

2. Value added from anchovy IDR. 144,050, -, small fish IDR. 252.350, -, shrimp centipede IDR. 13,250, -, and small squid IDR. 1.250, -

3. From the results of small crab processing, shrimp and small fish used as fish meal, value added: for small crabs IDR. 337,750, small shrimp/centipedes IDR 33.320, - and small fish IDR. 20,080, -

4. Value added leather Siteng, small shell, large shells have not done the treatment of value added

5. The raw material of shrimp and small shrimp has not done the value added treatment as row material making fish feed

\section{B. Suggestions}

Based on the description of the conclusions and the treatment conducted on the remaining catches of the trawling fisherman can be suggested as follows:

1. Need to make the formation of innovation group development of value added from the elements of the remaining catches of trawler fishing,

2. It is necessary to conduct research on the treatment of shrimp and small crabs commodity in producing livestock feed,

3. Need to do the formation of creative groups in processing value added of sea cucumber skin into various commodities jewelry,

4. Suggestions 1, 2 and 3 needs to be coordinated and financed by the government.

\section{REFERENCES}

[1] Budiharsono, 2005. Coastal Resources Management In Coastal Economic Development. 2005.

[2] Ramli, 2015. Conditions and Expectations of Regional Economic Development Infrastructure of North Sumatera in Confronting the Single Market Year 2015. Percentage Master plan Kek Seimangke. 2015.

[3] _ 2012 "The Perspective of Infrastructure and Spatial Readiness from the Special Economic Zone (Kek) Sei Mangkei of North Sumatra" Presented in the National Seminar at Auditorium Building of Simalungun University Thursday, November 1, 2012. 
[4] 2016. Acceleration of Agro-industry Development of Fisherman's Household Based on Crab Waste and Tilapia Fish in Bagan Percut Village, Percut Sei Tuan Sub-district, Deli Serdang Regency. Proposal.

[5] Tajerin. 2007. The Role of Technology in the Convergence of Economic Growth between Coastal Areas in Eastern Indonesia. Journal of Development Economics. Vol. 2 No. 3 2007. ISSN 1410-2641. Yogyakarta. Accredited, Decree Number: 55 / Dikti / Kep / 2005.
[6] Nurlina, ddk. 2016. Poverty Analysis of Fishermen in Coastal Aceh Timur. Dissertation, Faculty of Economics and Business University of North Sumatra. 2016

[7] Purwasih et al (2016) Comparative Analysis of Pure Seine Fishing Income and Pancing Tonda (troll line) at PPP Tamperan Pacitan, East Java. Fisheries Resources Utilization Management and Technology.

[8] Sugiyono. 2009. Quantitative and Qualitative Research Methods. R amd D. Alfabeta. Bandung. 